\title{
Field-monitored variations of soil moisture and matric suction in a saprolite slope
}

\author{
A.G. Li, Z.Q. Yue, L.G. Tham, C.F. Lee, and K.T. Law
}

\begin{abstract}
A full-scale field experiment has been conducted in an instrumented saprolite slope in Hong Kong. Soil moisture probes, tensiometers, piezometers, inclinometers, earth pressure cells, and a rain gauge were installed in the slope before and during excavation of a cut. This paper presents the results from soil moisture probes, tensiometers, and piezometers to reveal the surface infiltration process. The soil moisture and matric suction results show that the maximum "wetting front" during the wet season was limited to the top $3 \mathrm{~m}$ of soil, and a transient perched water table could develop in the soil during a very heavy rainstorm. A new method based on the variation of volumetric water content in the soil is proposed to analyze rainfall infiltration. The results indicate the following phenomena: $(i)$ rainfall infiltration was around $70 \%$ of the total rainfall, (ii) the infiltrated water mainly increased the soil moisture content of the soil at shallow depths, and (iii) the surface vertical infiltration had a very limited effect on the permanent groundwater table at depth. The wetting-front analysis shows that the unsaturated wetting band theory can be used to assess the movement of the wetting front in the unsaturated saprolite soil.
\end{abstract}

Key words: rainfall infiltration, moisture content, matric suction, wetting front, field instrumentation.

Résumé : Une expérience sur le terrain à grande échelle a été réalisée dans un talus d'excavation instrumenté dans du saprolite à Hong Kong. On a installé sur le site du talus, avant et pendant l'excavation, des instruments comprenant des sondes d'humidité, des tensiomètres, des piézomètres, des inclinomètres, des cellules de pression totale et des jauges de pluie. Cet article présente les résultats des sondes d'humidité et des tensiomètres qui indiquent le processus d'infiltration à la surface. Les résultats d'humidité du sol et de succion matricielle montrent que le front de saturation se limite au maximum aux $3 \mathrm{~m}$ supérieurs de profondeur durant la saison des pluies et qu'une nappe d'eau perchée transitoire peut se développer dans le sol durant une pluie torrentielle. On propose une nouvelle méthode basée sur la variation de la teneur en eau volumétrique du sol pour analyser l'infiltration de la pluie. Les résultats indiquent les phénomènes suivants: (i) l'infiltration de la pluie était d'environ $70 \%$ de la chute totale de pluie, (ii) l'eau infiltrée augmentait principalement la teneur en eau du sol à une faible profondeur, (iii) l'infiltration verticale à la surface avait un effet très limité sur la nappe d'eau permanente en profondeur. L'analyse du front de saturation montre que la théorie de la bande de sol non saturé peut être utilisée pour évaluer le mouvement du front de saturation dans le sol de saprolite non saturé.

Mots clés : infiltration de l'eau de pluie, teneur en eau, succion matricielle, front de saturation, instrumentation sur le terrain.

[Traduit par la Rédaction]

\section{Introduction}

Rainfall-induced slope failure is the most common type of landslide, particularly in Hong Kong (Lumb 1962, 1975; Brand et al. 1984; Au 1998; Franks 1999). Each year hundreds of small and large landslides occur during the wet season in Hong Kong. Despite the excellent efforts that have

Received 27 November 2002. Accepted 1 June 2004.

Published on the NRC Research Press Web site at http://cgj.nrc.ca on 4 February 2005.

A.G. Li, Z.Q. Yue, ${ }^{1}$ L.G. Tham, and C.F. Lee. Department

of Civil Engineering, The University of Hong Kong,

Pokfulam Road, Hong Kong, China.

K.T. Law. Department of Civil and Environmental

Engineering, Carleton University, 1125 Colonel By Drive,

Ottawa, ON K1S 5B6, Canada.

${ }^{1}$ Corresponding author (e-mail: yueqzq@hkucc.hku.hk). been made to improve slope safety, many issues are still not fully understood.

It is not uncommon for steep soil slopes to remain stable for many years, whereas some gentle slopes may fail during or soon after several heavy rainstorms. It has been well recognized that negative pore-water pressure (or matric suction) plays a crucial role in the stability of unsaturated soil slopes (Fredlund and Rahardjo 1993). When rainfall infiltrates the soil, the matric suction at shallow depths partially or completely disappears. Consequently, a slope failure may occur. For a rainfall-induced shallow landslide, the failure mechanism could be as follows: $(i)$ rainfall infiltration results in a decrease in the matric suction of the slope soils, (ii) the decrease in soil matric suction reduces the soil shear strength, and (iii) the reduction in soil shear strength subsequently causes the slope to become unstable and then fail. Furthermore, once the soil slope is completely saturated, the soil matric suction disappears completely. A perched water table with positive pore-water pressure would develop in the soil 
slope. The presence of a positive pore-water pressure would further decrease the soil shear strength and eventually trigger a rainfall-induced landslide.

To quantitatively investigate the mechanism of rainfallinduced slope failure, a full-scale cut-slope experiment was conducted at a hillside slope comprising saprolite in Hong Kong. This hillside slope was to be cut for road construction. A number of instruments were installed in the upper hillside slope before cutting and in the new cut slope during the cutting. The instruments included moisture probes, tensiometers, open standpipes, piezometers, inclinometers, earth pressure cells, and a rain gauge to measure moisture contents, matric suctions, groundwater levels, positive porewater pressures, horizontal soil deformation, horizontal earth pressures, and rainfall, respectively.

This paper describes the instrumentation for monitoring the responses of the pore pressure, both negative (suction) and positive, in the slope. The measured responses are reported and analyzed to give a quantitative understanding of the mechanism of rainfall-induced soil slope failures.

\section{Background}

A number of field experiments have been conducted to study the effects of rainfall infiltration on slope stability (Anderson 1983; Krahn et al. 1989; Lim et al. 1996; Zhang et al. 2000; Gasmo et al. 2000). Tensiometers are commonly used to monitor matric suction in the slope and can measure suctions up to $100 \mathrm{kPa}$ (Stannard 1992). As a result, most of the matric suction measurements with tensiometers in soils are within the shallow depth of $0.3-1.8 \mathrm{~m}$ below the ground surface (Anderson 1983; Krahn et al. 1989; Lim et al. 1996; Zhang et al. 2000). In particular, Gasmo et al. (2000) monitored the suction in soils up to a depth of $3.2 \mathrm{~m}$. Field measurements of soil moisture content are widely used in soil science (Nissen et al. 1999), agricultural water management (Inoue et al. 2001), and the study of climate change (Jipp et al. 1998). In geotechnical engineering, O'Kane et al. (1998) installed sensors to measure both matric suction and moisture content in monitoring an engineered soil cover system for waste rock.

The mechanism of rainfall-induced landslides and the relationship of landslide occurrence with rainfall patterns have been widely studied during the last 40 years (Lumb 1962, 1975; Brand et al. 1984; Finlay et al. 1997; Dai and Lee 2001). There have been many attempts to establish the relationship between rainfall and landslide occurrence. Lumb (1975) found that the disastrous rainfall events that could cause landslides were those in which the $24 \mathrm{~h}$ rainfall exceeded $100 \mathrm{~mm}$ and the 15 day antecedent rainfall exceeded $350 \mathrm{~mm}$. Brand et al. (1984) noted that the antecedent rainfall in Hong Kong was not a major factor in landslides, and the vast majority of landslides were induced by concentrated, short-duration rainfalls of high intensity $(>70 \mathrm{~mm} / \mathrm{h})$. Finlay et al. (1997) pointed out that the number of landslides was best predicted using the $3 \mathrm{~h}$ rainfall data. Dai and Lee (2001) showed that the $12 \mathrm{~h}$ rolling rainfall was of the most importance in predicting the number of landslides. The $12 \mathrm{~h}$ rolling rainfall is defined as the cumulative rainfall for a $12 \mathrm{~h}$ period and is calculated using the rainfall gauge records at the interval of $5 \mathrm{~min}$.
Lumb (1962) derived a wetting-band equation for the case of one-dimensional infiltration in the vertical direction. This equation has become the well-known Lumb's wetting-band theory and has been used in addressing the issue of soil moisture and suction in a soil mass in association with rainfall infiltration. This theory has also been used in geotechnical engineering practice to roughly predict the levels of groundwater tables above a relatively impermeable surface such as bedrock in slopes in Hong Kong (GEO 1984). Sun et al. (1997) attempted to extend Lumb's wetting-band theory to cover unsaturated soil slopes.

Despite the existence of abundant field and laboratory data, there are still many uncertainties in accurately estimating the soil moisture, matric suction, and groundwater level in relation to rainfall infiltration. There is still a great need for quality field data to clarify the uncertainties (D.G. Fredlund, personal communication, 2003). It is clear, therefore, that a full-scale field experiment under confirmed conditions will be helpful to clarify some of the important issues in slope performance.

\section{Site description}

Many factors were considered when selecting a slope for the instrumented monitoring to establish an ideal study site. First, the site had to be free of vandalism so that the instrumentation system would not be disturbed during the course of the full-scale experiment; second, the soil condition at the site had to be the typical of those in Hong Kong. Because of funding constraints, it was not possible to cut a large slope exclusively devoted to the research. Instead, the instrumented cut slope had to be part of an actual construction project.

The selected slope was a typical hillside slope in Hong Kong (Fig. 1). A major road was planned along the lower part of the hillside and was to be constructed by cutting the lower part of the slope. Therefore, the slope was selected for the quantitative investigation of slope performance during cut excavation and rainfall events (Fig. 2). The history of the slope site was established from an interpretation of a sequential series of aerial photographs and a review of relevant records of landslides and ground investigation. The site had a number of slope instabilities in both natural hillside and man-made cut slopes. In particular, a landslide occurred at the site on 2-3 July 1997 (GEO 1999). This landslide was about $200 \mathrm{~m}$ from the selected hillside slope and had a debris volume of $3000 \mathrm{~m}^{3}$. It is typical of rainfall-induced landslides in Hong Kong.

The selected slope site was an existing natural hillside terrain covered by mature vegetation and trees. There are two natural stream courses down the hillside adjacent to the selected slope. The slope originally had a gentle slope angle of $20^{\circ}$. In 2001, the hillside was excavated to accommodate the road construction. The excavation resulted in a cut slope $17.5 \mathrm{~m}$ high and a $1.5 \mathrm{~m}$ wide berm at the middle level. After excavation, the slope angle was about $30^{\circ}$ (Fig. 3). An access country road was located about 60-70 m horizontal distance above the cut slope (Fig. 4). 
Fig. 1. Site photograph showing the hillside slope condition before road excavation in 2000

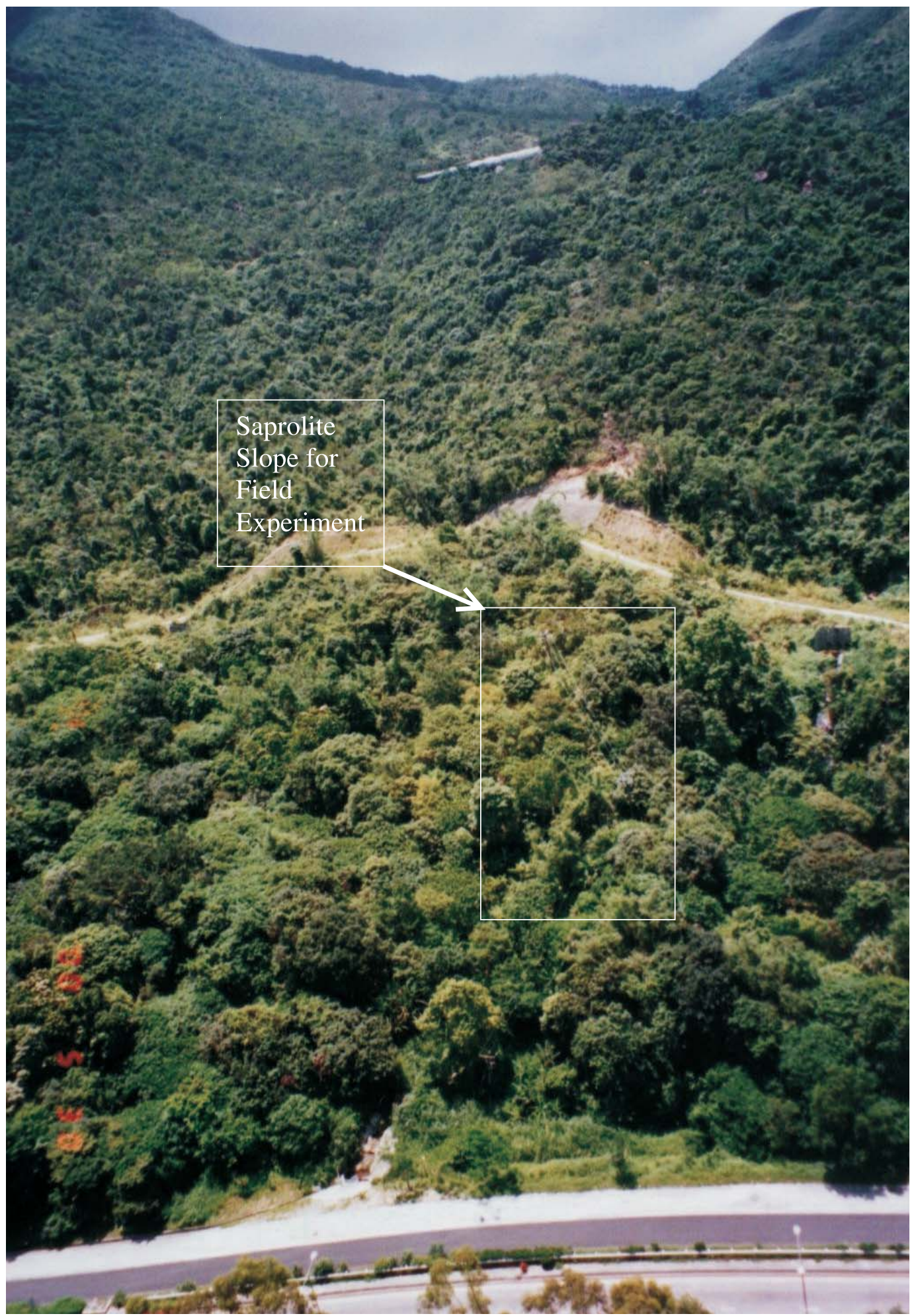

\section{Soil properties}

The instrumented cut slope comprises mainly a saprolite soil. This saprolite soil is the typical completely decomposed granite (CDG) soil of Hong Kong and is underlain by highly decomposed granite (HDG) and then moderately decomposed granite (MDG).
Boreholes were drilled in the original hillside slope before the excavation and in the cut slope berm during the excavation for soil samples, in situ testing, and installation of instruments. The exact locations and number of boreholes are shown in Fig. 2. Undisturbed Mazier soil samples representing the upper $4 \mathrm{~m}$ thick saprolite soil were obtained from the boreholes during the two stages of site investigation and in- 
Fig. 2. Location plan of the boreholes and slope instrumentation system.

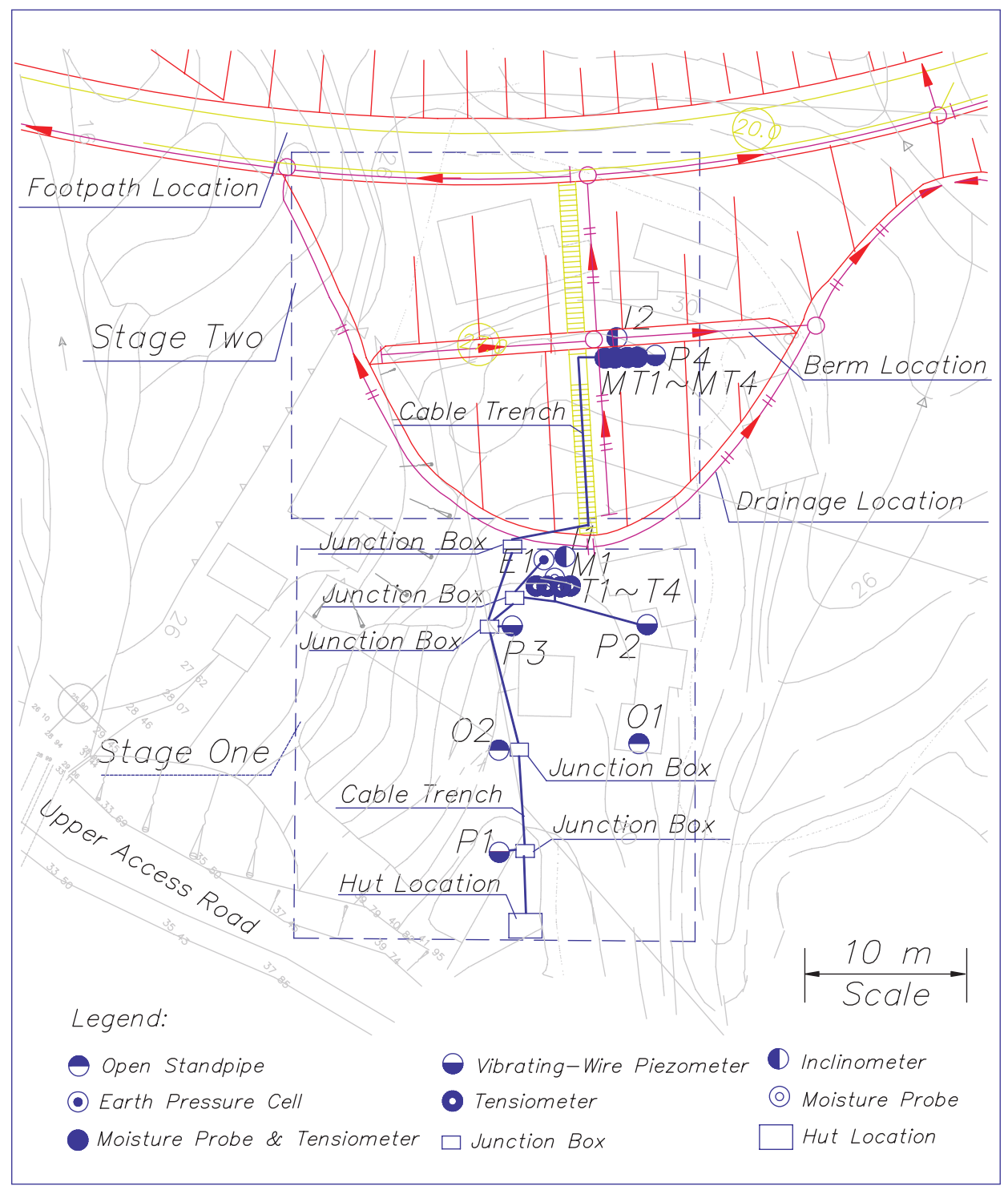

strumentation. The saprolite, as revealed by site investigation, is completely decomposed, medium-grained granite. It can be classified as a very weak to weak, light brown to brown, silty-clayey sand. Guelph permeameter tests were also carried out to determine the field saturated hydraulic conductivity.

The laboratory test program to characterize the soil properties includes the following tests: (i) bulk density, (ii) dry density, (iii) specific gravity, (iv) Atterberg limits, and (v) particle-size distribution. The laboratory results are summarized in Table 1. The particle-size distribution curves for the soil samples from borehole M1 at the crest are shown in Fig. 5. The results in Fig. 5 show that the soil within the $2.0 \mathrm{~m}$ shallow depth and behind the crest area had higher silt and clay contents $(44.6 \%)$.

The soil-water characteristic curve represents a relation between soil matric suction and soil volumetric water content. It is essential in understanding the behaviour of unsaturated soils. The soil-water characteristic curves were measured in the laboratory using both the drying and wet- ting paths. The test samples are the soils within the $2 \mathrm{~m}$ shallow depth and immediately behind the crest area. The results are shown in Fig. 6. The air-entry value (AEV) for the soil sample behind the crest was approximately 5$10 \mathrm{kPa}$.

\section{Instrumentation system}

\section{Recalibration of instruments}

Before their installation in the field, all the instruments were checked in the laboratory for proper functioning. Furthermore, the moisture probes, tensiometers, piezometers, and earth pressure cells were recalibrated.

\section{Moisture probe}

Moisture probes were used to measure volumetric water content in the soil. The moisture probe had a total length of $215 \mathrm{~mm}$, a diameter of $40 \mathrm{~mm}$, and three $60 \mathrm{~mm}$ long needles. The needle separation was $14 \mathrm{~mm}$, and the three needles can be either pushed into the soil or buried in the soil. 
Fig. 3. Typical geological cross section. CDG, completely decomposed granite; HDG, highly decomposed granite; MDG, moderately decomposed granite; mPD, metres above Hong Kong Principal Datum.

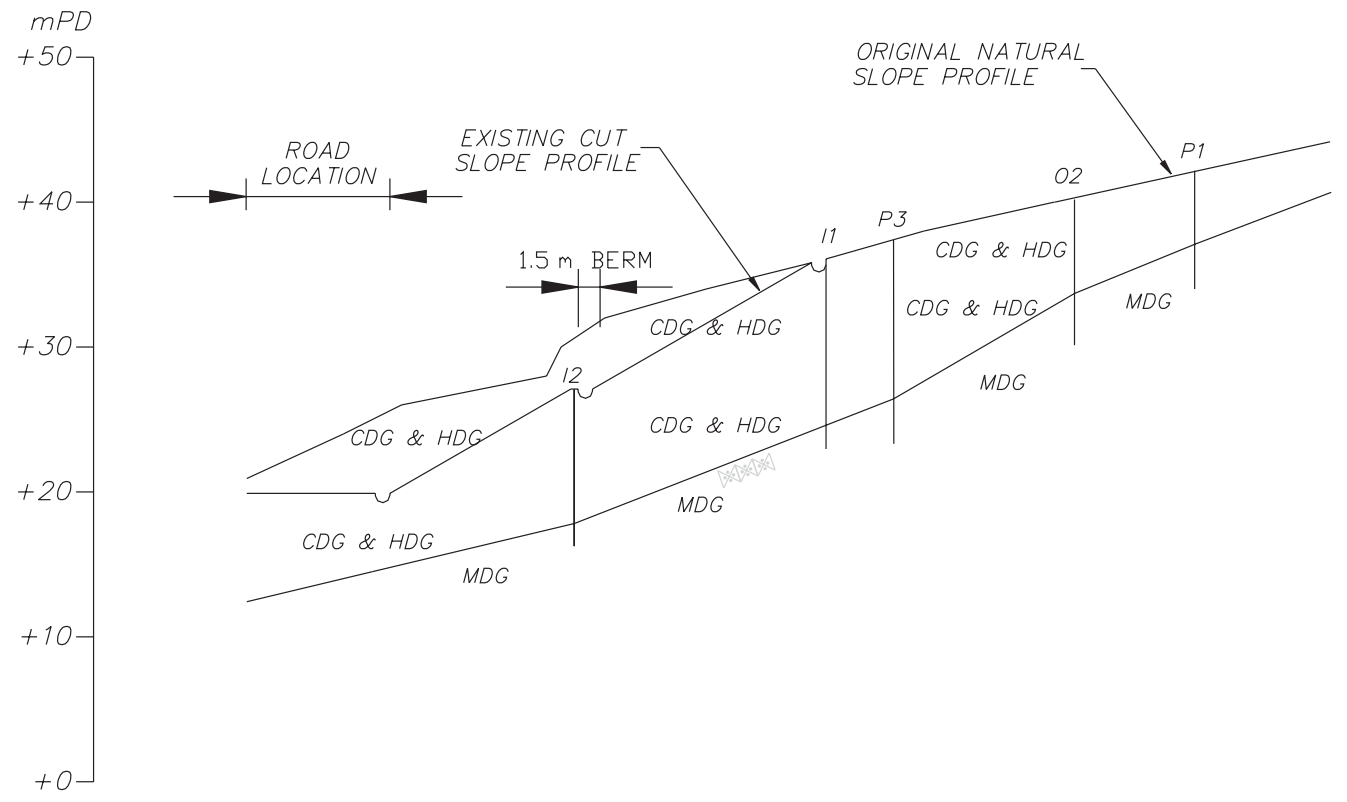

Fig. 4. Site photograph showing the cut slope and hillside slope condition after road excavation in December 2001.

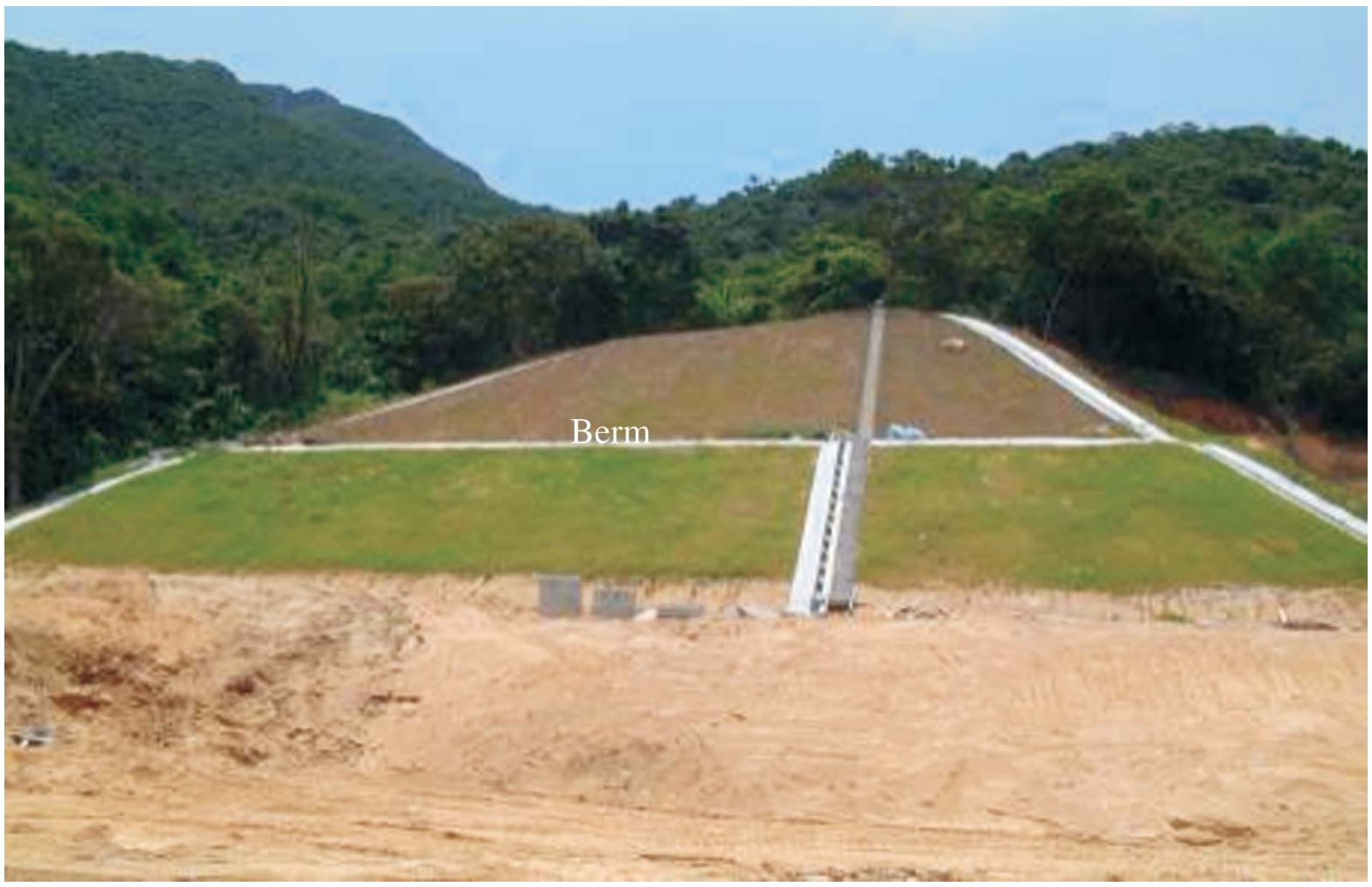

Each moisture probe had a high-frequency moisture detector that used the standing-wave principle to indicate the ratio of two or more substances forming a body of material. Each substance had a different dielectric constant. By measuring the change in the dielectric constant, one can determine the soil water content. The output of the moisture probes is in volts. The results obtained from the moisture probes, using the formula provided by the vendor, were expected to be within $\pm 2 \%-5 \%$ of the actual water content determined in the laboratory. After they were recalibrated with the specific soil, the results could be within $\pm 2 \%$ of the actual water content.

To recalibrate the moisture probe, it was necessary to simply compare the probe output in volts with the volumetric water content of the soil samples obtained in the field. The volumetric water content was determined using the values of 
Table 1. Soil properties of saprolite soil (CDG) at the crest and near the berm of the instrumented slope.

\begin{tabular}{lll}
\hline & \multicolumn{2}{l}{ Location } \\
\cline { 2 - 3 } & At the crest & Near the berm \\
\hline Bulk density $\left(\mathrm{Mg} / \mathrm{m}^{3}\right)$ & $1.88-1.93$ & $1.76-1.83$ \\
Dry density $\left(\mathrm{Mg} / \mathrm{m}^{3}\right)$ & $1.50-1.54$ & $1.44-1.48$ \\
Specific gravity & $2.627-2.655$ & $2.629-2.653$ \\
Void ratio & $0.731-0.788$ & $0.788-0.844$ \\
Porosity & $0.42-0.44$ & $0.44-0.46$ \\
Liquid limit $(\%)$ & $54.2-67.1$ & $46.0-49.2$ \\
Plastic limit $(\%)$ & $36.4-44.3$ & $31.5-34.6$ \\
Plasticity index $(\%)$ & $18-23$ & $12-18$ \\
Gravel content $(\leq 62 \mathrm{~mm} ; \%)$ & $12.4-22.3$ & $14.4-20.2$ \\
Sand content $(\leq 2 \mathrm{~mm} ; \%)$ & $42.8-50.8$ & $67.1-70.3$ \\
Silt content $(\leq 63 \mu \mathrm{m} ; \%)$ & $15.3-25.9$ & $9.0-18.3$ \\
Clay content $(\leq 2 \mu \mathrm{m} ; \%)$ & $11.60-18.90$ & $0.24-0.51$ \\
Saturated hydraulic conductivity $(\mathrm{m} / \mathrm{s})$ & $1 \times 10^{-6}-1 \times 10^{-5}$ & $1 \times 10^{-6}-1 \times 10^{-5}$ \\
\hline
\end{tabular}

Fig. 5. Particle-size distribution curves for soil samples in borehole M1 at the crest.

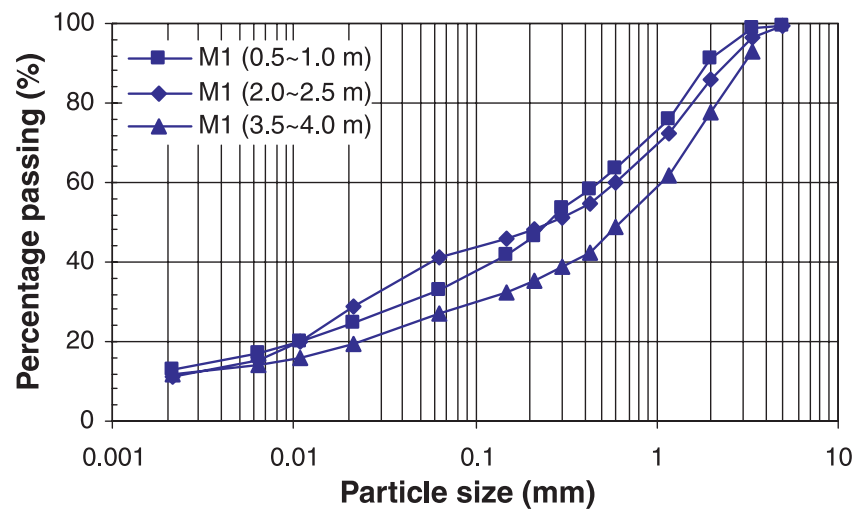

Fig. 6. Laboratory-measured soil-water characteristic curves for the soil sample at $2 \mathrm{~m}$ depth in borehole M1 at the crest.

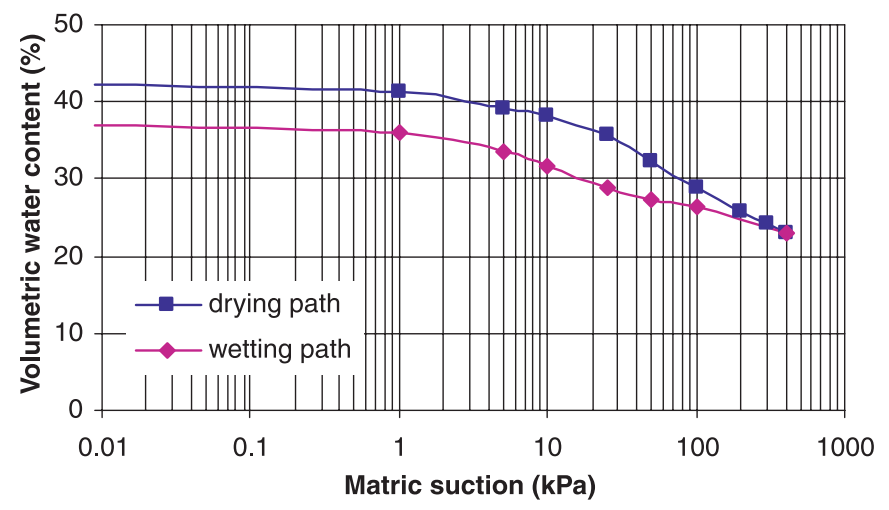

the gravimetric water content, the specific gravity of the soil particles, and the void ratio of the soil sample. The resultant regression of the output in volts and the volumetric water content obtained in the laboratory resulted in the recalibration formulae for the probes.

\section{Tensiometer}

Vibrating-wire tensiometers were used to measure matric suction in the soil. The tensiometers had a diameter of
$22 \mathrm{~mm}$ and were of different lengths. Each tensiometer had a water-filled plastic tube, a high air entry ceramic tip sealed at the toe of the tube, and a pressure transducer and jet-fill cap sealed at the head of the tube. The jet-fill cap served as a reservoir to allow easy refilling with water and deairing of the tensiometer.

When the tensiometer tube was filled with water and inserted into the soil, water could move into and out of the tensiometer through the connecting pores in the ceramic tip. As the soil was drying, water would move out of the tensiometer, creating a vacuum inside the tensiometer tube as indicated by the pressure transducer. When the vacuum was just equal to the matric suction, water would stop flowing out of the tensiometer. The pressure transducer reading was then a direct measurement of the force required to remove water from the soil. If the soil dried further, additional water would move out until a higher vacuum level was reached. When the water content of the soil increased, the reverse process would take place. Water from the soil would move back into the soil tensiometer through the porous ceramic tip until the vacuum level was reduced to equal the lower soil suction value. At equilibrium, the water movement stopped. If the soil was saturated, the pressure transducer reading would drop to zero.

Theoretically, the tensiometer was capable of measuring suctions up to $100 \mathrm{kPa}$, but water in the tensiometer tube was observed to cavitate at a pressure of approximately $-90 \mathrm{kPa}$. Therefore, the difference in elevation head between the pressure transducer and the ceramic tip of the tensiometer had to be corrected. The longer the tensiometer tube, the greater the correction. After correction, the actual maximum measurable suctions for tensiometers buried at depths of $1,2,3$, and $4 \mathrm{~m}$ would be about $80,70,60$, and $50 \mathrm{kPa}$, respectively.

The porous ceramic tips of the tensiometers did not need recalibration, but the pressure transducers of the tensiometers should be recalibrated. The output of the pressure transducer of each tensiometer was a digital signal. There were two factors to be recalibrated, the linear gauge factor and the thermal factor. The linear gauge factor was related to the applied pressure and was recalibrated at the same 
temperature under different applied pressures. The thermal factor was related to the applied temperature and was recalibrated at the same pressure under different applied temperatures.

\section{Piezometer}

The vibrating-wire piezometers were used to measure positive pore-water pressures in the deep ground. The positive pore-water pressures could be transferred to static groundwater level. Each vibrating-wire piezometer had a length of $133.35 \mathrm{~mm}$ and a diameter of $25.40 \mathrm{~mm}$ and could be either buried in the soil or installed in the open standpipes.

The working principle of the vibrating-wire piezometer was the same as that of the vibrating-wire transducers in the tensiometers. The output of the vibrating-wire piezometer was also in digital form and had to be converted to either pore-water pressure or ground-water level. The recalibration formula for each vibrating-wire piezometer was also similar to that of the pressure transducer. The only difference was that the pore-water pressure in the piezometer recalibration formula was expressed in water head level.

\section{Details of instrument installation}

The installation of instruments was divided into two stages. Each stage was carried out at a location and during a time period such that the installation would not interfere with the road construction activities. The first stage was to monitor the performance of the slope before and during the formation of the cut slope by excavation. The second stage was to monitor the performance of the cut slope during and after the slope excavation. The instrument installation during the first stage was carried out at the hillside slope above the proposed cut slope and before the cut slope was formed. This stage began in March 2001 and was completed in July 2001. Four moisture probes, four tensiometers, six standpipes, eight piezometers, three earth pressure cells, one inclinometer, and one rain gauge were installed. The excavation of the cut slope started in early November 2001. When the first cut slope batter was formed by excavation, the second stage of instrument installation was carried out at the berm immediately below the first cut slope batter. The second stage began in November 2001 and was completed in December 2001. At the end of this stage, the formation of the entire cut slope was also completed. Four moisture probes, four tensiometers, two piezometers, and one inclinometer were installed during the second stage.

Detailed ground investigation was carried out during the two stages of instrument installation. The ground investigation included 18 boreholes, undisturbed Mazier sampling, standard penetration tests, and in situ falling-head permeability tests. Among the 18 boreholes, nine were used for the installation of moisture probes and tensiometers. The other nine boreholes were used for the installation of open standpipes, piezometers, inclinometers, and earth pressure cells. Figure 2 shows the locations of the boreholes and the layout plan of the instrumentation system.

\section{Moisture probe}

A total of eight moisture probes were used to measure soil moisture contents in different parts of the slope. Four moisture probes were installed at depths of 1, 2, 3, and $4 \mathrm{~m}$ in borehole M1 above the cut slope during the first stage. The other four moisture probes were installed in boreholes MT1, MT2, MT3, and MT4 at depths of 1, 2, 3, and $4 \mathrm{~m}$, respectively, in the cut slope berm during the second stage.

To install the four moisture probes at the cut crest area, a $100 \mathrm{~mm}$ diameter and $4 \mathrm{~m}$ deep borehole (M1) was drilled with a hydraulic drilling machine. The first moisture probe was placed on the bottom of the borehole at $4 \mathrm{~m}$ depth. The borehole was then backfilled up to $3 \mathrm{~m}$ depth with the in situ CDG soil. The CDG soil was well compacted to the original density. The second moisture probe was then placed on top of the compacted soil at $3 \mathrm{~m}$ depth in borehole M1. Similarly, the other two moisture probes were installed at depths of 2 and $1 \mathrm{~m}$ in borehole M1. To avoid any infiltration "short-circuiting" during heavy rainfall, $200 \mathrm{~mm}$ thick bentonite-cement grouting was added to the borehole at each of the $3.5,2.5,1.5$, and $0.5 \mathrm{~m}$ depths.

To install the four moisture probes in the cut slope immediately above the berm, four $100 \mathrm{~mm}$ diameter boreholes MT1, MT2, MT3, and MT4 were drilled to depths of 1, 2, 3, and $4 \mathrm{~m}$, respectively. Each of the four boreholes was installed with one moisture probe and one tensiometer.

\section{Tensiometer}

A total of eight tensiometers were used to measure soil matric suctions at different locations in the slope. Four of the tensiometers were installed in boreholes T1, T2, T3, and $\mathrm{T} 4$ at depths of $1,2,3$, and $4 \mathrm{~m}$, respectively, above the cut slope during the first stage. The other four were installed in boreholes MT1, MT2, MT3, and MT4 at depths of 1, 2, 3, and $4 \mathrm{~m}$, respectively, immediately above the cut slope berm during the second stage.

Prior to installation, initial readings were taken for all pressure transducers. To install the tensiometers in the crest area, four $100 \mathrm{~mm}$ diameter boreholes were drilled using a hydraulic drilling machine. The four boreholes were drilled to depths of $0.9,1.9,2.9$, and $3.9 \mathrm{~m}$, and then a $25 \mathrm{~mm}$ diameter coring tool was used to core a small hole $100 \mathrm{~mm}$ deep into the bottom of each of the boreholes. This hole was used to accommodate the ceramic tip of a tensiometer.

Once the ceramic tip of a tensiometer was inserted into the small hole of each of the four boreholes, the bottom $0.5 \mathrm{~m}$ of the borehole was backfilled above the ceramic tip with the in situ CDG soil and then well compacted. A $200 \mathrm{~mm}$ thick layer of bentonite-cement grout was then added to each borehole to avoid any infiltration "shortcircuiting" during heavy rainfall. The borehole was then filled with the CDG soil and well compacted. The soil around the tensiometer tube at the ground surface was also well compacted to prevent rainwater from ponding along the tensiometer tube and prematurely reaching the ceramic tip.

The installation of tensiometers immediately above the berm was similar to that at the crest area except that the former had one moisture probe and one tensiometer in each of the four boreholes.

\section{Piezometer}

A total of eight vibrating-wire piezometers were used to measure positive pore-water pressures at different locations in the slope. Six were installed in boreholes P1, P2, and P3 in the natural hillside above the cut slope during the first in- 
Fig. 7. Variations of the volumetric water content (borehole M1) and daily rainfall from June to December 2001. Dates given as month-day-year.

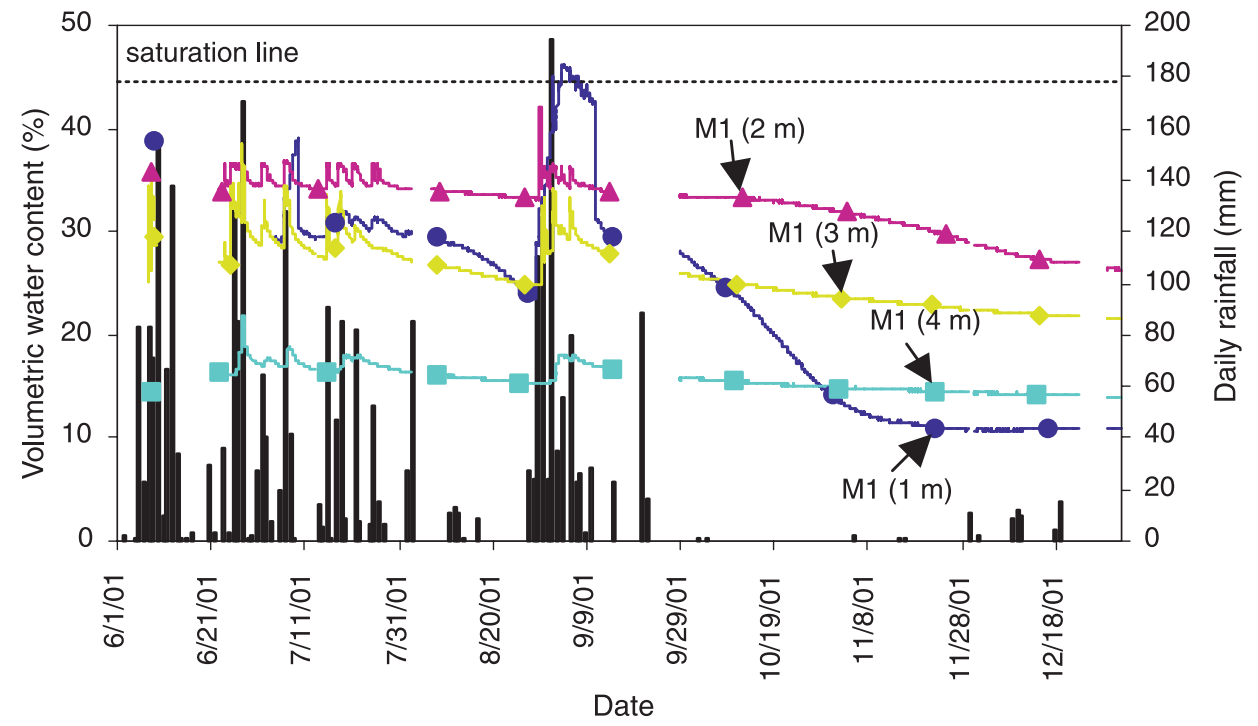

stallation stage, and the other two were installed in borehole $\mathrm{P} 4$ in the cut slope berm during the second installation stage.

To install the piezometers, four $114 \mathrm{~mm}$ diameter boreholes were drilled into the bedrock for about 2.0-5.0 m using a hydraulic drilling machine. The bedrock is MDG, and clean water was used as the drilling medium.

Two piezometers were installed in each borehole at two different depths. Particular attention was paid to sealing the borehole sections between the two piezometers. As a result, each of the two piezometers could correctly measure the pore-water pressures in its own response zone. After completion of drilling, each borehole was flushed with clean water to clean out the drill cuttings. Cement-bentonite grout was placed using a tremie pipe at the bottom of the borehole and filled to the required depth. The grout mix was prepared using a ratio of 1:1:6 cement-bentonite-water.

After the cement-bentonite grout had been placed for about $5 \mathrm{~h}$, bentonite pellets were dropped into the borehole immediately above the grout. Water was then added for about $3 \mathrm{~h}$ to swell the bentonite pellets. After the settlement of the bentonite pellets, the piezometer was lowered to the design depth. With the piezometer held at its design depth, clean sand was placed around it to form the first response zone. Immediately above the first response zone, the borehole was sealed with the second layer of bentonite pellets.

The borehole was sealed with a second layer of cementbentonite grout to the design depth for the installation of the second piezometer. A third layer of bentonite pellets was placed above the grout in the borehole. The second piezometer was then installed using the same method as that for the first piezometer. After installation of the second piezometer, the borehole was sealed with grout up to the ground surface.

\section{Data acquisition system}

An automatic data acquisition system was set up for the full-scale field experiment to monitor the moisture content, matric suction, pore-water pressure, horizontal earth pressure, and rainfall in real time on a continuous basis.
Groundwater levels in the open standpipes and horizontal deformation in the two inclinometers were manually measured on a periodic basis.

A dipmeter was used for the groundwater levels in the open standpipe. A stream of puckets was used to record the groundwater level in the open standpipes between the periodic manual measurements. A portable inclinometer probe was used to measure the horizontal displacements in the two inclinometers, and rainfall was monitored with an independent integral logger and tipping-bucket rain gauge in real time.

An instrumentation hut was constructed near the access road $50 \mathrm{~m}$ above the cut slope to house the dataloggers and power supplies. The automatic data acquisition system consisted of the sensors, cables, dataloggers, and power supplies. The dataloggers were configured to collect data at a 15 min interval. The data were downloaded weekly or biweekly. The instruments for the measurement of soil moisture and suction were part of the automatic data acquisition system for the cut slope experiment.

\section{Field monitoring results}

\section{Soil moisture probe and tensiometer}

Figures 7 and 8 show the variations of volumetric water content and matric suction in the ground immediately above the crest of the cut slope for the period between June and December 2001. By examining the volumetric water content and matric suction records and their comparisons with daily rainfall for the same period, the following observations are made:

(1) Variations in volumetric water content at the different depths with time were different. The volumetric water content was generally high during the wet season (May to September) and low and stable during the dry season (October to December).

(2) Variations in matric suction at the different depths with time were different. The matric suction was low during 
Fig. 8. Variations of the matric suction results (boreholes T1-T4) and the daily rainfall from June to December 2001. Dates given as month-day-year.

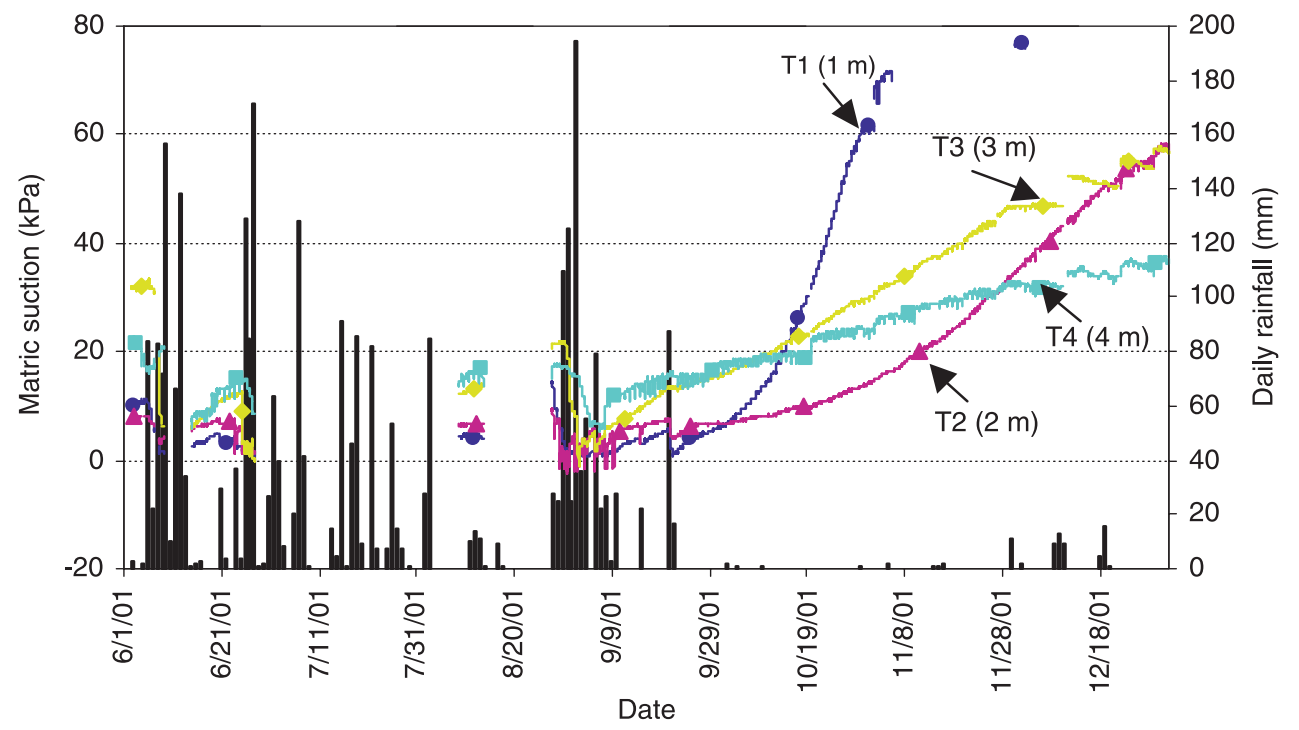

the wet season (May to September) and high during the dry season (October to December).

(3) The volumetric water content increased due to rainfall infiltration during the wet season and decreased mainly due to evaporation after rainfall during the wet season or during the dry season. The matric suction decreased during the wet season and increased during the dry season.

(4) Variations in volumetric water content and matric suction at the different depths were different. The maximum variations often occurred near the ground surface (i.e., at a depth of $1 \mathrm{~m}$ ), and the magnitudes of the variations generally decreased with an increase in depth.

(5) The maximum variations in volumetric water content and matric suction often occurred in the top $3 \mathrm{~m}$ of soil. Only heavy rainfall events such as those on 1 September 2001 could slightly increase the volumetric water content and decrease the matric suction at a depth of $4 \mathrm{~m}$. Such small variations may explain why many of the slope failures in this region during heavy rainstorms were shallow landslides.

(6) The matric suction at a depth of $1 \mathrm{~m}$ probably exceeded the limit $(80 \mathrm{kPa})$ of the tensiometer during the dry season of 2001.

Figures 9 and 10 show the volumetric water content and matric suction records and their comparisons with the 15 min rainfall from 27 August to 11 September 2001. The following observations are made:

(1) The volumetric water content and matric suction near the ground surface at a depth of $1 \mathrm{~m}$ were the first to be affected by rainfall infiltration. Some delays of about 6$12 \mathrm{~h}$ in the variations of volumetric water content and matric suction were observed at a depth of $4 \mathrm{~m}$ during the heaviest rainfall on 1 September 2001. Such delays were possibly due to the greater infiltration of soil pore water flow in the ground after the heavy rainfall.

(2) Although antecedent rainfall also influenced the volumetric water content and matric suction, the recorded high-intensity $15 \mathrm{~min}$ rainfall resulted in a significant increase in volumetric water content and decrease in matric suction. These results imply that the localized short-duration rainfalls of high intensity had a much greater effect than the long-duration rainfalls of low intensity.

(3) The volumetric water content also decreased soon after a rainfall stopped (for example, on 31 August 2001), although not to the original level, and the matric suction increased.

(4) During the heaviest rainfall, which occurred on 1 September 2001 (194.5 mm/day), the recorded matric suction from the tensiometers at depths of 1 and $2 \mathrm{~m}$ reached zero, and the recorded volumetric water content of the moisture probes at 1 and $2 \mathrm{~m}$ reached the value of soil porosity. Therefore, the top $2 \mathrm{~m}$ of soil was possibly fully saturated. A transient perched water flow was assumed to have developed in the top $2 \mathrm{~m}$.

(5) The antecedent rainfall infiltration contributed to the increase in volumetric water content and decrease in matric suction, with the magnitudes of the increase or decrease dependent on the intensity of the antecedent rainfall.

\section{Piezometer}

Figure 11 shows the variations of the groundwater level in borehole P2 in the slope above the cut slope crest for the period between June and December 2001. By examining the groundwater level records and their comparisons with daily rainfall for the same period, the following observations are made:

(1) The highest water levels in P2 were recorded on 4 September 2001, and a heavy rainfall of $194.5 \mathrm{~mm} /$ day occurred on 1 September. Therefore, there was a time lag before the highest groundwater level was recorded at the location of borehole P2. This time lag was possibly due to the greater infiltration of soil pore water flow after the heavy rainfall.

(2) The groundwater level in borehole P2 increased about $2.5 \mathrm{~m}$ due to the heavy rainfall on 1 September 2001. 
Fig. 9. Variations of the volumetric water content (borehole M1) and the 15 min rainfall from 27 August to 11 September 2001 . Dates given as month-day.

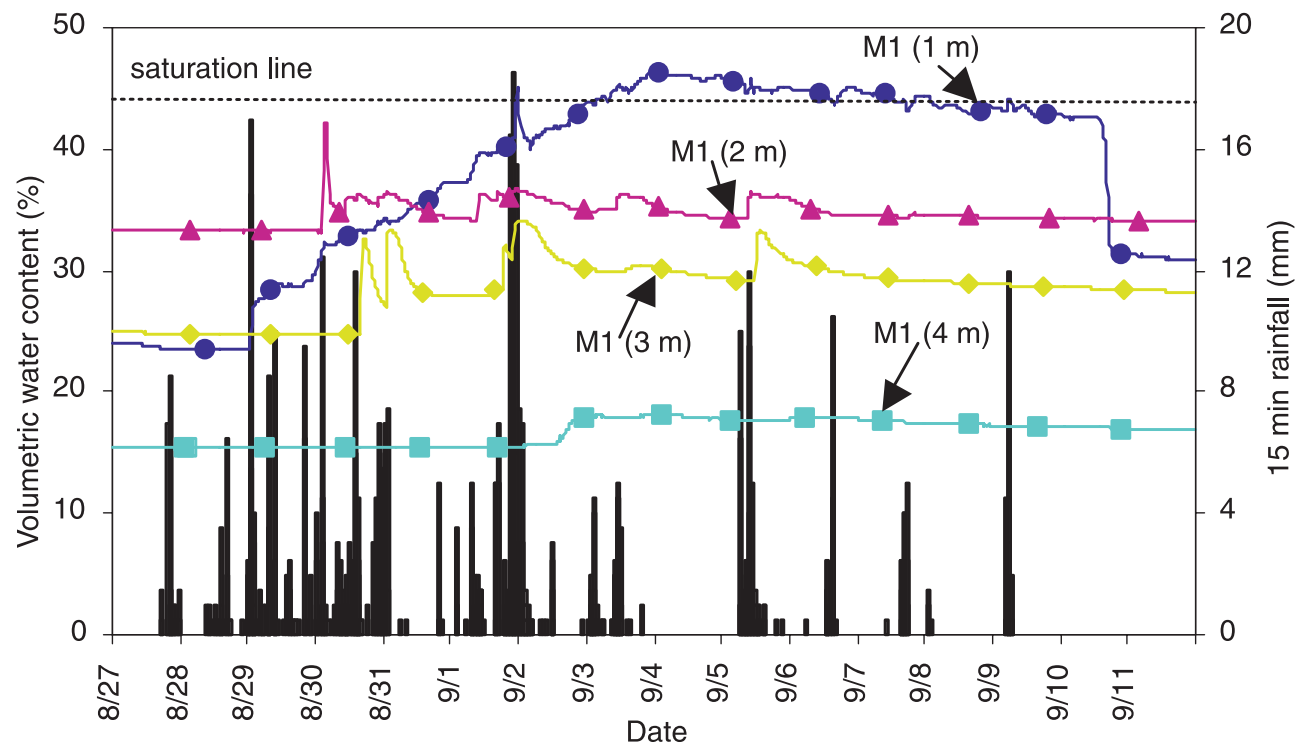

Fig. 10. Variations of the matric suction results (boreholes T1-T4) and the 15 min rainfall from 27 August to 11 September 2001. Dates given as month-day.

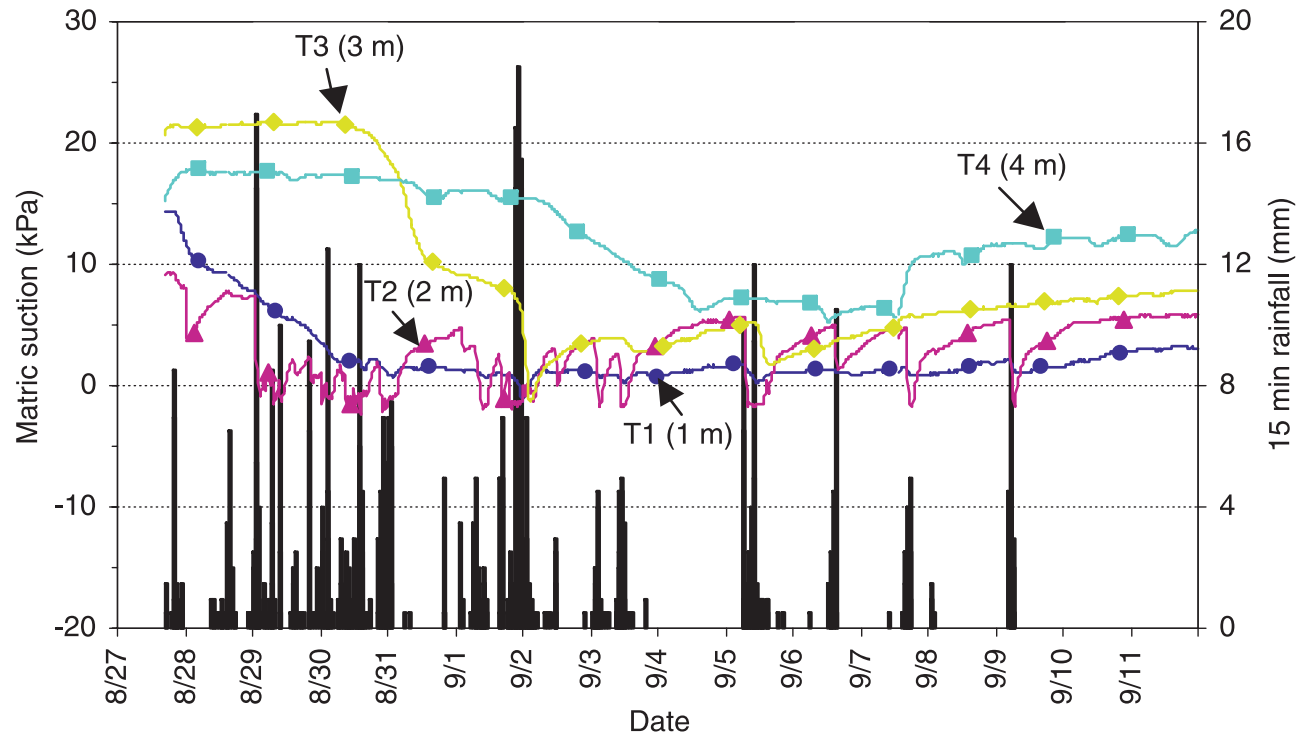

(3) The groundwater level in borehole P2 decreased slowly after reaching its highest level.

(4) Because there was a time lag, antecedent rainfall may contribute significantly to the rise of the permanent groundwater level at depth. This may imply that antecedent rainfall, especially when heavy, has a greater influence on deep-seated landslides.

\section{Moisture content and matric suction profiles}

The variations of the moisture content and matric suction profiles in the hillside slope during the wet season are examined to obtain a clear understanding of the rainfall infiltration process. The volumetric water content was converted to degree of saturation. The variations in degree of saturation and matric suction with depth from 28 August to 3 September 2001 due to rainfall infiltration are shown in Figs. 12 and 13, respectively. The results in these two figures show the movement of the wetting front due to precipitation. By examining the movement of the wetting front in terms of the degree of saturation and matric suction data for this time period, the following observations are made:

(1) The wetting front can move downward in unsaturated soil, which shows that the low-intensity antecedent rainfall also increased the volumetric water content.

(2) Although antecedent rainfall also increased the volumetric water content, a transient perched water table (or 
Fig. 11. Variations of the groundwater level (borehole P2) and daily rainfall from June to December 2001. Dates given as month-dayyear.

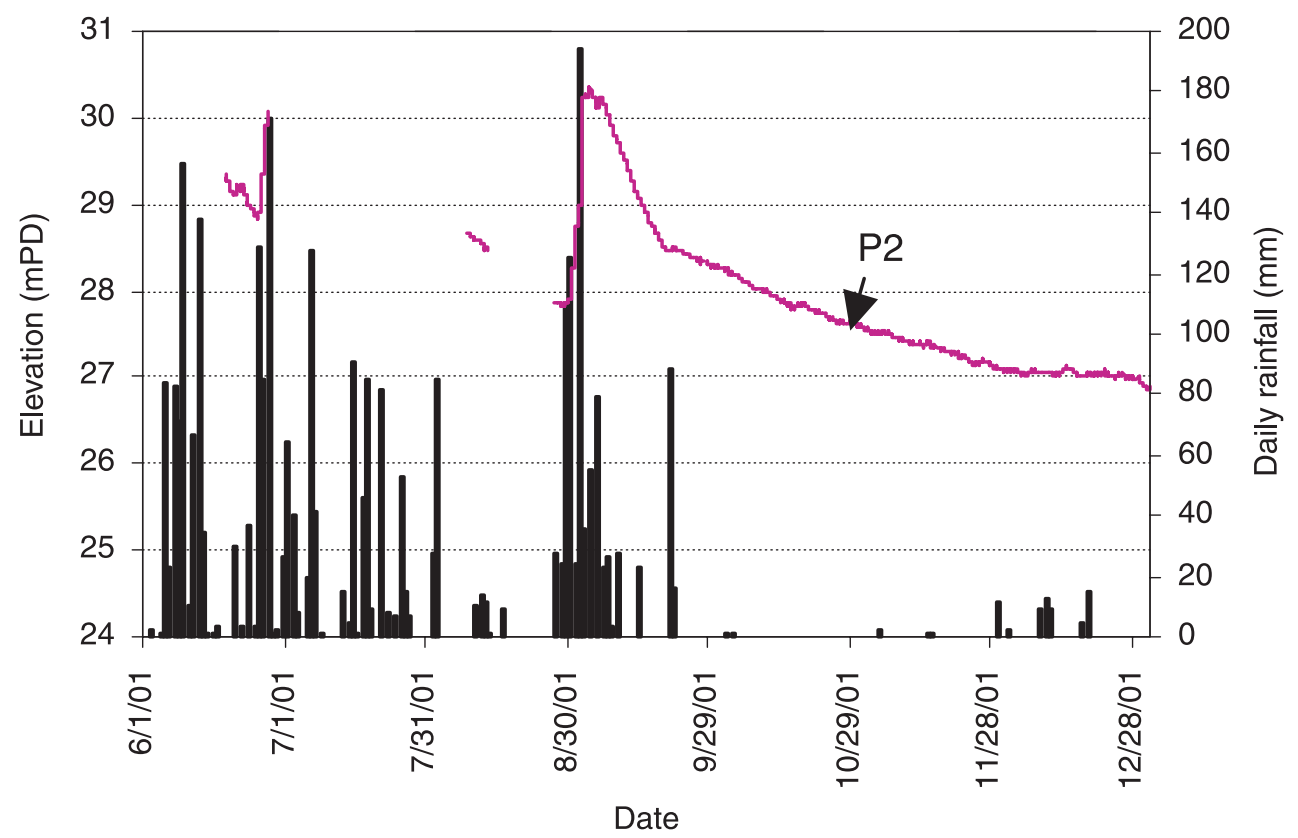

Fig. 12. Variations of the degree of saturation at borehole M1 with depth and time. Dates given as month-day-year.

Degree of saturation

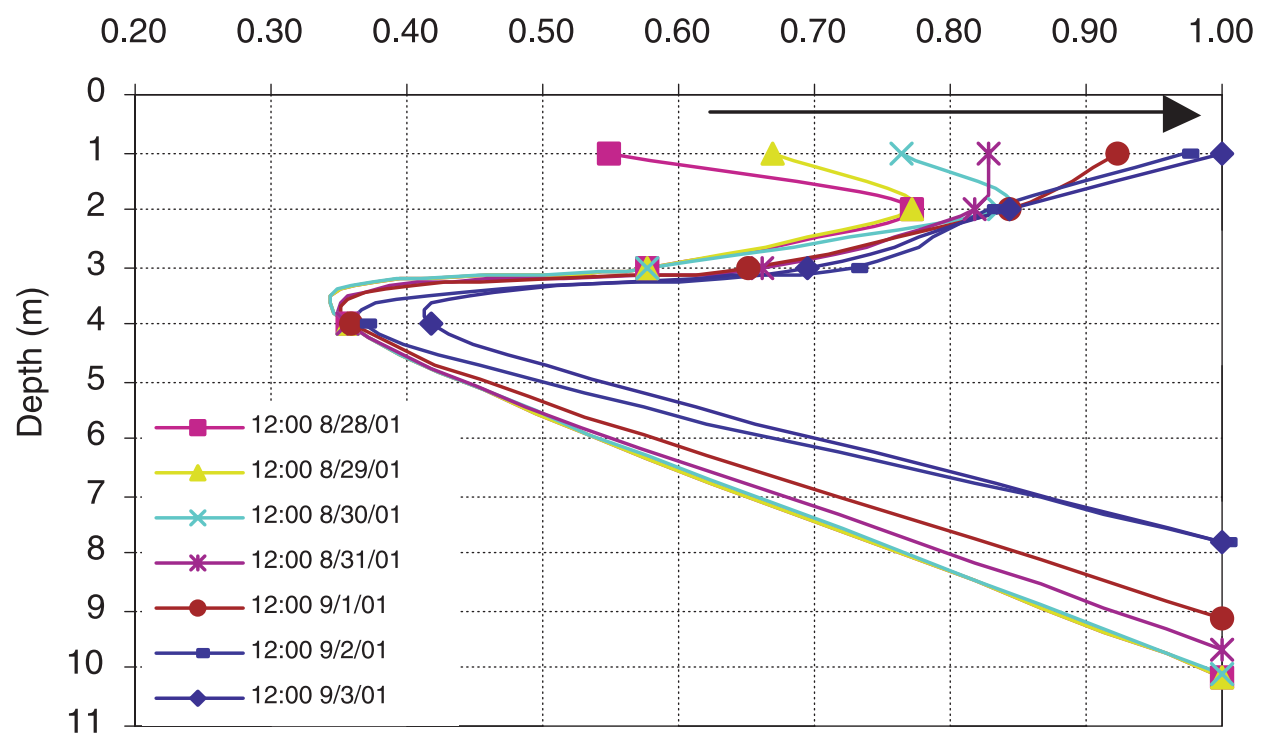

positive pore-water pressure in the fully saturated soil) developed in the top $2 \mathrm{~m}$ of soil only due to the heavy rainfall on 1 September 2001 (194.5 mm/day). This result shows that a high-intensity rainfall can increase the volumetric water content in the soil to a saturated state.

(3) The volumetric water content at a depth of $4 \mathrm{~m} \mathrm{did} \mathrm{not}$ change until 3 September 2001, but the deep groundwater level rose about $2.5 \mathrm{~m}$ before 3 September (Fig. 12). Therefore, it is concluded that the rise in the groundwater table in the test slope was due to the seepage water from the upper hillside slope.

\section{Rainfall infiltration analysis}

Infiltration rate analysis

To understand the rainfall infiltration process, the fieldmonitored data from the moisture probes were further analyzed using a new method illustrated in the following.

On the basis of the moisture content profiles such as those in Fig. 12, the net increase with time in the amount of water in the soil due to surface infiltration can be calculated. In the calculation, the volumetric water content profile at a specific time is taken as the reference value. The net increase in vol- 
Fig. 13. Variations of the matric suction results at boreholes T1-T4 with depth and time. Dates given as month-day-year.

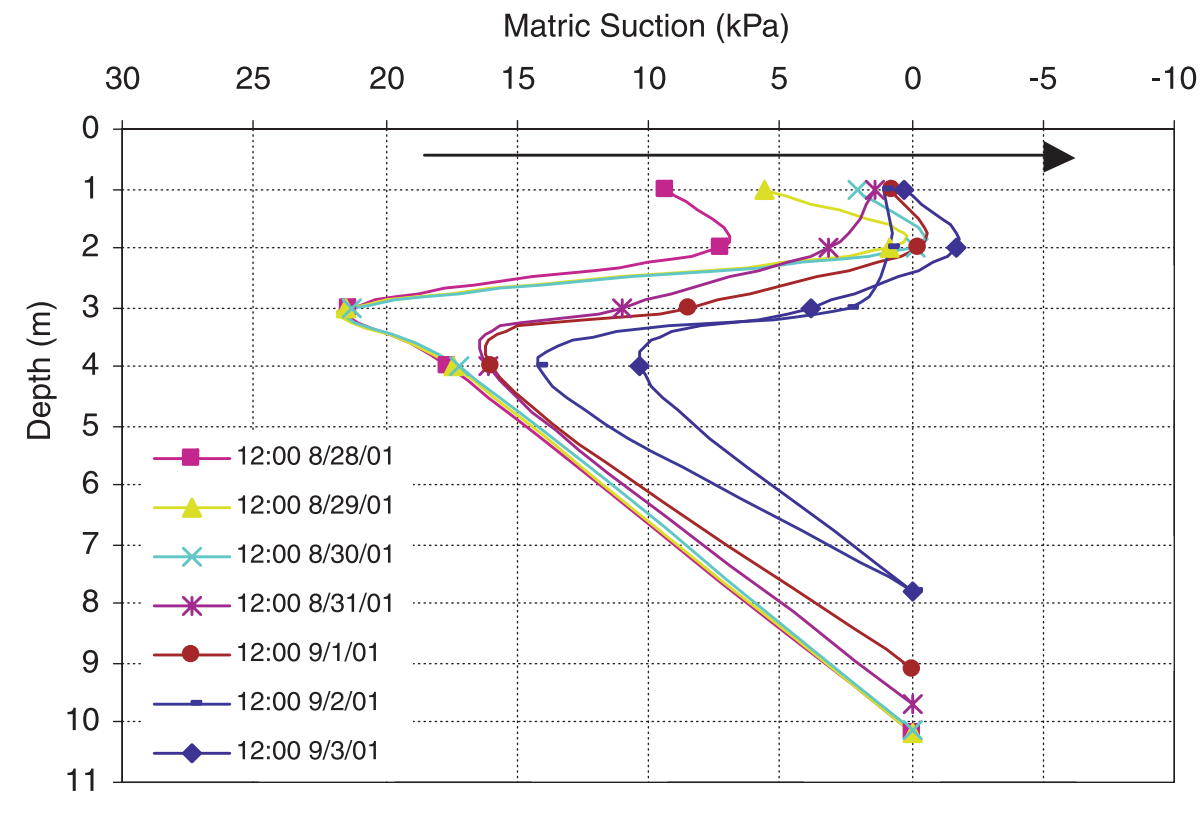

Fig. 14. Variations of the estimated cumulative infiltration $(I)$ and the monitored cumulative rainfall $(R)$ with time. Dates given as month-day.

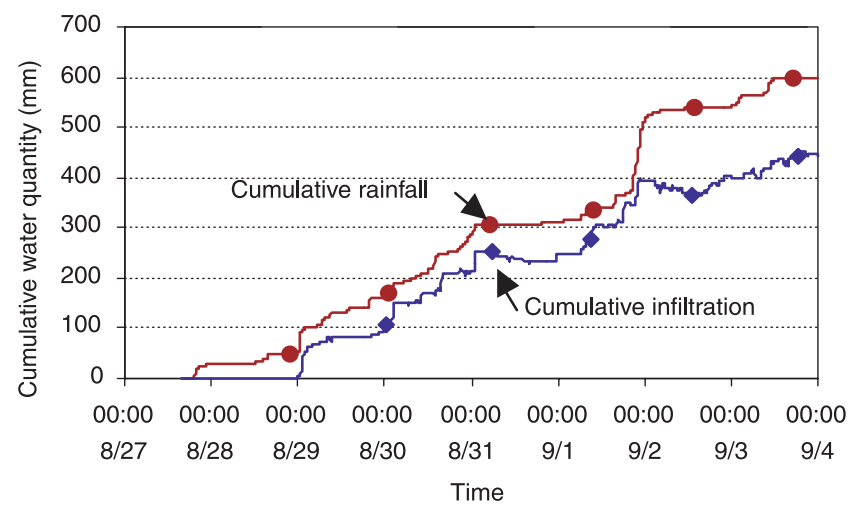

umetric water content at any time after the reference time is calculated from the variation of the volumetric water content line. It is further assumed that the top $1 \mathrm{~m}$ of soil has the same volumetric water content as that measured at a depth of $1 \mathrm{~m}$.

Figure 14 illustrates the variations of the estimated cumulative infiltration and the recorded cumulative rainfall with time. It is evident that the estimated cumulative infiltration was increasing proportionally with the increase in the recorded cumulative rainfall. Based on the results, the cumulative infiltration coefficient can also be estimated. The cumulative infiltration coefficient can be defined as the ratio of the cumulative infiltration to the cumulative rainfall. Table 2 gives the cumulative rainfall, cumulative infiltration, and cumulative infiltration coefficients for several days in August and September 2001. The results show that the cumulative infiltration coefficient was between 0.59 and 0.75 , which is consistent with previous measurements on vegetated CDG soils in Hong Kong (DSD 1995).

The rainfall intensity and infiltration rate during each day
Table 2. Cumulative rainfall, infiltration, and infiltration coefficient for several days in August and September 2001.

\begin{tabular}{lccc}
\hline & $\begin{array}{l}\text { Cumulative } \\
\text { rainfall, } \\
R(\mathrm{~mm})\end{array}$ & $\begin{array}{l}\text { Cumulative } \\
\text { infiltration, } \\
I(\mathrm{~mm})\end{array}$ & $\begin{array}{l}\text { Cumulative } \\
\text { infiltration } \\
\text { coefficient }(\%)\end{array}$ \\
Date & 27.5 & 0 & 0 \\
Aug. 27 & 52.0 & 0 & 0 \\
Aug. 28 & 162.0 & 95 & 59 \\
Aug. 29 & 16.0 & 209 & 73 \\
Aug. 30 & 287.5 & 234 & 75 \\
Aug. 31 & 312.0 & 382 & 75 \\
Sept. 1 & 506.5 & 403 & 74 \\
Sept. 2 & 542.0 & 448 & 75 \\
Sept. 3 & 597.5 & & \\
\hline
\end{tabular}

Table 3. Daily rainfall intensity, infiltration rate, and infiltration coefficient for several days in August and September 2001.

\begin{tabular}{lllc}
\hline & $\begin{array}{l}\text { Rainfall } \\
\text { intensity, } \\
q_{\mathrm{R}}(\mathrm{m} / \mathrm{s})\end{array}$ & $\begin{array}{l}\text { Infiltration } \\
\text { rate, } \\
q_{\mathrm{I}}(\mathrm{m} / \mathrm{s})\end{array}$ & $\begin{array}{l}\text { Infiltration } \\
\text { coefficient } \\
(\%)\end{array}$ \\
Day & $3.2 \times 10^{-7}$ & 0 & 0 \\
Aug. 27 & $2.8 \times 10^{-7}$ & 0 & 0 \\
Aug. 28 & $2.3 \times 10^{-6}$ & $1.1 \times 10^{-6}$ & 86 \\
Aug. 29 & $1.3 \times 10^{-6}$ & $1.3 \times 10^{-6}$ & 87 \\
Aug. 30 & $1.5 \times 10^{-7}$ & $2.8 \times 10^{-7}$ & 100 \\
Aug. 31 & $2.8 \times 10^{-6}$ & $1.8 \times 10^{-6}$ & 76 \\
Sept. 1 & $2.3 \times 10^{-6}$ & $1.3 \times 10^{-7}$ & 84 \\
Sept. 2 & $4.1 \times 10^{-7}$ & $5.2 \times 10^{-7}$ & 81 \\
Sept. 3 & $6.4 \times 10^{-7}$ & 5.25 \\
\hline
\end{tabular}

are estimated and the results are given in Table 3, which shows that the lower the rainfall intensity, the higher the rainfall infiltration coefficient. The calculated zero infiltration rates on 27 and 28 August 2001 are due to the assump- 
Table 4. Comparison of the measured (Meas.) and estimated (Est.) saturated hydraulic conductivity $k_{\mathrm{s}}$, final degree of saturation $S_{\mathrm{f}}$, and depth of wetting front $h$.

\begin{tabular}{|c|c|c|c|c|c|c|c|c|c|}
\hline \multicolumn{2}{|c|}{ Time interval (month-day-time) } & \multirow[b]{2}{*}{$\begin{array}{l}\text { Meas. } \\
q_{\mathrm{R}}(\mathrm{m} / \mathrm{s})\end{array}$} & \multirow[b]{2}{*}{$\begin{array}{l}\text { Meas. } \\
S_{0}\end{array}$} & \multicolumn{2}{|l|}{$\underline{S_{\mathrm{f}}}$} & \multicolumn{2}{|l|}{$k_{\mathrm{s}}(\mathrm{m} / \mathrm{s})$} & \multicolumn{2}{|l|}{$h(\mathrm{~m})$} \\
\hline From & To & & & Meas. & Est. & Meas. & Est. & Meas. & Est. \\
\hline 08-29-00:00 & $08-30-02: 15$ & $1.4 \times 10^{-6}$ & 0.63 & 0.72 & 0.76 & $1 \times 10^{-6}-1 \times 10^{-5}$ & $7.7 \times 10^{-6}$ & 2.0 & 2.30 \\
\hline 08-29-00:00 & $08-30-15: 45$ & $1.4 \times 10^{-6}$ & 0.60 & 0.70 & 0.76 & $1 \times 10^{-6}-1 \times 10^{-5}$ & $7.8 \times 10^{-6}$ & 2.5 & 2.80 \\
\hline 09-1-00:00 & $09-1-23: 45$ & $2.3 \times 10^{-6}$ & 0.74 & 0.86 & 0.87 & $1 \times 10^{-6}-1 \times 10^{-5}$ & $7.2 \times 10^{-6}$ & 3.0 & 3.40 \\
\hline 09-1-20:00 & $09-1-23: 45$ & $9.4 \times 10^{-6}$ & 0.89 & 1.00 & 1.00 & $1 \times 10^{-6}-1 \times 10^{-5}$ & $8.4 \times 10^{-6}$ & 1.0 & 1.02 \\
\hline
\end{tabular}

tion that the volumetric water content on the ground surface is equal to that at a depth of $1 \mathrm{~m}$.

\section{Wetting front analysis}

Sun et al. (1997) extended Lumb's saturated wetting band theory to cover the situation of rainfall infiltration in unsaturated soils under the condition that the rainfall intensity $q_{\mathrm{R}}$ is less than the saturated hydraulic conductivity $k_{\mathrm{s}}$. The following formula was proposed to estimate the depth of the unsaturated wetting front:

$$
h=\frac{\left(k-k_{0}\right) t}{n\left(S_{\mathrm{f}}-S_{0}\right)} \approx \frac{q_{\mathrm{R}} t}{n\left(S_{\mathrm{f}}-S_{0}\right)}
$$

where $h$ is the depth of the unsaturated wetting front, $k_{0}$ is the initial unsaturated hydraulic conductivity, $k$ is the unsaturated hydraulic conductivity at time $t, t$ is the rainfall duration, $n$ is the porosity, $S_{0}$ is the initial degree of saturation, $S_{\mathrm{f}}$ is the final degree of saturation at time $t$, and $q_{\mathrm{R}}$ is the rainfall intensity $\left(q_{\mathrm{R}} \leq k_{\mathrm{s}}\right)$.

In the case where $k$ is equal to $k_{\mathrm{s}}$ and is much greater than $k_{0}$, eq. [1] is reduced to Lumb's saturated wetting band equation. To calculate the depth of the unsaturated wetting front, the final degree of saturation $S_{\mathrm{f}}$ due to the rainfall must be determined and can be found from the unsaturated hydraulic conductivity function. From the empirical hydraulic conductivity function given by Averjanov in 1950 (Fredlund et al. 1994), the unsaturated hydraulic conductivity can be written as follows:

$$
k=k_{\mathrm{s}}\left(\frac{\theta-\theta_{\mathrm{r}}}{\theta_{\mathrm{s}}-\theta_{\mathrm{r}}}\right)^{3.5}
$$

where $\theta_{\mathrm{r}}$ is the residual volumetric water content, at which the effectiveness of suction to cause further drainage to the liquid phase begins to diminish; $\theta_{\mathrm{s}}$ is the saturated volumetric water content, which is equal to the porosity $n$; and $\theta$ is the volumetric water content corresponding to $k$.

From eq. [1], when the rainfall intensity $q_{\mathrm{R}}$ is less than the saturated hydraulic conductivity $k_{\mathrm{s}}$, we have

$$
\text { [3] } k \approx k_{0}+q_{\mathrm{R}}
$$

The initial hydraulic conductivity corresponding to $k_{0}$ can be calculated from eq. [2] using the initial volumetric water content $\theta_{0}$ and the saturated hydraulic conductivity $k_{\mathrm{s}}$. Once $k_{0}$ is calculated, $k$ can be calculated from eq. [3]. The degree of saturation $S_{\mathrm{f}}$ corresponding to $k$ and hence $\theta$ can be found from eq. [2], and the depth of the unsaturated wetting front $h$ can then be estimated using eq. [1].
The saturated hydraulic conductivity $k_{\mathrm{s}}$ of the site can also be calculated from the measured depth of the wetting front $h$. For example, from the time 00:00 on 29 August 2001 to 02:15 on 30 August 2001, the measured depth of the wetting front $h$ was $2.0 \mathrm{~m}$. The initial average degree of saturation $S_{0}$ within the top $2 \mathrm{~m}$ of soil was 0.63 . The measured final average volumetric water content $S_{\mathrm{f}}$ within the top $2 \mathrm{~m}$ of soil was 0.72 . The residual volumetric water content $\theta_{\mathrm{r}}$ was 0.1 (see M1 (1 m) in Fig. 7), and the soil porosity was 0.45 . From eq. [2], the initial unsaturated hydraulic conductivity $k_{0}$ at $\theta_{0}$ is equal to $0.10 k_{\mathrm{s}}$, and the unsaturated hydraulic conductivity $k$ at $\theta$ is equal to $0.21 k_{\mathrm{s}}$. Substituting the values of these parameters into eq. [1] gives $k_{\mathrm{s}}=7.7 \times 10^{-6} \mathrm{~m} / \mathrm{s}$. The calculated saturated hydraulic conductivity is in the same range as that of the field-measured Guelph permeameter values (i.e., $1 \times 10^{-6}$ to $1 \times 10^{-5} \mathrm{~m} / \mathrm{s}$ ).

The depth of the wetting front $h$ is estimated based on the average calculated saturated hydraulic conductivity $\left(k_{\mathrm{s}}=\right.$ $7.8 \times 10^{-6} \mathrm{~m} / \mathrm{s}$ ). Table 4 shows a comparison of the measured and estimated saturated hydraulic conductivity $k_{\mathrm{s}}$, final degree of saturation $S_{\mathrm{f}}$, and depth of the wetting front $h$. A reasonable agreement exists between the measured and estimated values.

From this wetting front analysis, the advance of the wetting front depends not only on the rainfall intensity, but also on the unsaturated hydraulic conductivity function and the initial moisture content. The initial moisture content can influence the depth of the wetting front. When the rainfall intensity is greater than the saturated hydraulic conductivity, a saturated wetting front or a transient water table can be observed. This is why more shallow landslides occur in Hong Kong.

\section{Conclusions}

The instrumentation system for a full-scale field experiment at a saprolite slope has been presented. The system was monitored regularly in 2001. The results and discussions on the variations of soil moisture content, matric suction, and groundwater level in the saprolite slope lead to the following conclusions:

(1) The movements of the "wetting front" were different depending on the rainfall pattern. The maximum movement of the wetting front often occurred in the upper $3 \mathrm{~m}$ of soil.

(2) A transient perched water table was observed to develop within the upper $2 \mathrm{~m}$ of soil during the heaviest rainfall in the monitored period. 
(3) The antecedent rainfall had some influence on the increase in soil moisture content and the decrease in matric suction and a significant influence on the rise of the permanent groundwater level at depth.

(4) A new method based on the variation of volumetric water content in the soil has been proposed to analyze rainfall infiltration. The results show that the actual infiltration rate was around $70 \%$ of the total rainfall, that rainfall infiltration mainly increased the soil moisture content, and that the surface vertical infiltration had a very limited effect on the permanent groundwater level at depth.

(5) The wetting front analysis shows that the unsaturated wetting band theory could be used to assess the movement of the wetting front in the unsaturated saprolite

\section{Acknowledgements}

The work presented in this paper was financially supported by the Research Grants Council of Hong Kong (Research Grant HKU 7123/99E) and the Hong Kong Jockey Club Charities Trust. The authors would also like to thank the in-kind support from the Works Bureau, the Territory Development Department, and the Geotechnical Engineering Office of the Hong Kong SAR Government, China Harbour Engineering Co. (Group), Maunsell Geotechnical Services Ltd., Maunsell Consultants Asia Ltd., and Vibro (HK) Ltd. The authors would also like to thank the Editor, Professor Arun J. Valsangkar, the Associate Editor, and the two reviewers for their invaluable comments and suggestions which have enhanced the paper presentation.

\section{References}

Anderson, M.G. 1983. The prediction of soil suction for slopes in Hong Kong, final report. Geotechnical Control Office, Public Works Department, Hong Kong.

$\mathrm{Au}$, S.W.C. 1998. Rain-induced slope instability in Hong Kong. Engineering Geology, 51: 1-36.

Brand, E.W., Premchitt, J., and Phillipson, H.B. 1984. Relationship between rainfall and landslides. In Proceedings of the 4th International Symposium on Landslides, Toronto, Ont., 16-21 September 1984. BiTech Publishers, Vancouver, B.C. Vol. 1, pp. 377-384.

Dai, F.C., and Lee, C.F. 2001. Frequency-volume relation and prediction of rainfall-induced landslides. Engineering Geology, 59(3-4): 253-266.

DSD. 1995. Stormwater drainage manual: planning, design and management. 2nd ed. Drainage Services Department (DSD), Hong Kong Government, Hong Kong.

Finlay, P.J., Fell, R., and Maguire, P.K. 1997. The relationship between the probability of landslide occurrence and rainfall. Canadian Geotechnical Journal, 34: 811-824.
Franks, C.A.M. 1999. Characteristics of some rainfall-induced landslides on natural slopes, Lantau Island, Hong Kong. Quarterly Journal of Engineering Geology, 32: 247-259.

Fredlund, D.G., and Rahardjo, H. 1993. Soil mechanics for unsaturated soils. John Wiley \& Sons, Inc., New York.

Fredlund, D.G., Xing, A., and Huang, S. 1994. Predicting the permeability function for unsaturated soils using the soil-water characteristic curve. Canadian Geotechnical Journal, 31: 533546.

Gasmo, J.M., Hritzuk, K.J., Rahardjo, and Leong, E.C. 2000. Instrumentation of an unsaturated residual soil slope. Geotechnical Testing Journal, 22(2): 128-137.

GEO. 1984. Geotechnical manual for slopes. Geotechnical Engineering Office (GEO), Civil Engineering Department, Hong Kong Government, Hong Kong.

GEO. 1999. Investigation of some selected landslide incidents in 1997. Vol. 4. Geotechnical Engineering Office (GEO), Civil Engineering Department, Hong Kong SAR Government, Hong Kong.

Inoue, Y., Watanabe, T., and Kitamura, K. 2001. Prototype timedomain reflectometry probes for measurement of moisture content near the soil surface for applications to "on-the-move" measurements. Agricultural Water Management, 50(1): 41-52.

Jipp, P.H., Nepstad, D.C., Cassel, D.K., and De Carvalho, C.R. 1998. Deep soil moisture storage and transpiration in forests and pastures of seasonally dry amazonia. Climatic Change, 39(2-3): 395-412.

Krahn, J., Fredlund, D.G., and Klassen, M.J. 1989. Effect of soil suction on slope stability at Notch Hill. Canadian Geotechnical Journal, 26: 269-278.

Lim, T.T., Rahardjo, H., Chang, M.F., and Fredlund, D.G. 1996. Effect of rainfall on matric suctions in a residual soil slope. Canadian Geotechnical Journal, 33: 618-628.

Lumb, P. 1962. Effect of rainstorms on slope stability. In Proceedings of the Symposium on Hong Kong Soils, Hong Kong. pp. 73-87.

Lumb, P. 1975. Slope failures in Hong Kong. Quarterly Journal of Engineering Geology, 8: 31-65.

Nissen, H.H., Moldrup, P., De Jonge, L.W., and Jacobsen, O.H. 1999. Time domain reflectometry coil probe measurements of water content during fingered flow. Soil Science Society of America Journal, 63(3): 493-500.

O'Kane, M., Wilson, G.W., and Barbour, S.L. 1998. Instrumentation and monitoring of an engineered soil cover system for mine waste rock. Canadian Geotechnical Journal, 35: 828-846.

Stannard, D.I. 1992. Tensiometers - theory, construction, and use. Geotechnical Testing Journal, 15(1): 48-58.

Sun, H.W., Wong, H.N., and Ho, K.K.S. 1997. Analysis of infiltration in unsaturated ground. In Slope Engineering in Hong Kong: Proceedings of the Annual Seminar on Slope Engineering in Hong Kong, Hong Kong, 2 May 1997. Edited by K.S. Li, J.N. Kay, and K.K.S. Ho. A.A. Balkema, Rotterdam, The Netherlands. pp. 101-109.

Zhang, J., Jiao, J.J., and Yang, J. 2000. In situ rainfall infiltration studies at a hillside in Hubei Province, China. Engineering Geology, 57(1): 31-38. 